\title{
Values, identities and social constructions of the European Union among Turkish university youth
}

\author{
NURAN HORTACSSU ${ }^{1 *}$ AND \\ NEVRA CEM-ERSOY ${ }^{2}$ \\ ${ }^{1}$ Department of Psychology, Middle East Technical \\ University, Ankara, Turkey \\ ${ }^{2}$ Institute of Psychology, Erasmus University \\ Rotterdam, The Netherlands
}

\begin{abstract}
The present study aimed to investigate Turkish university youth's constructions concerning the European Union (EU) and their reactions to the EU's December 2002 Copenhagen summit decision to delay discussion of Turkey's entry to the EU. Specifically it aimed to show that socio-political identities among Turkish youth were related to historical developments in Turkey's past and that these identities had associations with values of ethnocentricism, patriotism, and secularism. Furthermore it was predicted that constructions of the EU reactions to the decision would be related. Students (400) from five universities at the three largest cities of Turkey participated in the study. Three identities, Nationalist-Islam, Kemalist, and Western; three constructions of the EU, Europe as Different, Impermeable Boundaries, and Different but Advantageous, and two perceived causes for the decision, Differences-Conflict and Justification emerged from factor analyses. Second order factor analysis revealed that Nationalist-Islam identity and authoritarian, ethnocentric and antisecular values formed a cluster whereas Kemalist and Western identities were grouped with low levels of patriotism. Positive and negative constructions of the EU and reactions to the Copenhagen decision were also grouped under two separate factors. Further analyses revealed that an index of urbanization composed of parental education and rural-urban origin predicted the Authoritarian-Nationalistic cluster and that this value-identity cluster predicted positive and negative views of the EU. Copyright (C) 2004 John Wiley \& Sons, Ltd.
\end{abstract}

The present study aimed to investigate Turkish university youth's constructions concerning the European Union (EU) and their reactions to the EU's December 2002 Copenhagen summit decision to delay discussion of Turkey's entry to the EU. Turkey has been trying to join the EU since the 1950s. At the summit, Turkey's introduction of new regulations concerning economic and democratic reforms

*Correspondence to: Nuran Hortaçsu, Department of Psychology, Middle East Technical University, Ankara, Turkey.

E-mail: hortac@metu.edu.tr

Contract/grant sponsor: Middle East Technical University; contract/grant number: BAP 2003-07-03-00-04. 
was acknowledged, but it was declared that the implementation of the regulations should be observed. The study was conducted during the weeks following the EU's Copenhagen decision.

The study had four specific aims: (1) To investigate dimensions of constructions concerning the EU among Turkish university youth. (2) To show that these constructions are related to reactions to the Copenhagen decision. (3) To show that various social identities endorsed by university students are related to values associated with ideological issues in Turkey's recent past. 4) To show that values and social identities are related to constructions of EU.

\section{HISTORICAL BACKGROUND OF TURKISH-EUROPEAN RELATIONS}

Sherif (1966) and Tajfel (1981) proposed that historical context should be considered while analysing intergroup phenomena. From a historical stance, religious differences and conflict have characterized Turkish-European relations (Kuran-Burçoğlu, 2003; Soykut, 2003). During the 14th to 16th centuries, Europe equated 'Turk' with the expansionist power of Islam. Turkish power waned after the 17th century and most Ottoman lands were seized by European powers after the WW1. Turkey fought a war of independence, recovered some lands, abolished the Ottoman reign, and established the Turkish Republic in 1923. After the foundation of the Republic, Turkey adopted secularism and accelerated attempts at westernization. Despite pressures from Britain, Turkey did not enter the WWII and had to face postwar Soviet threats alone (Kongar, 1998). After the 1950s, Turkish workers migrated to Europe and presently constitute sizable minorities facing discriminatory attitudes from their hosts (Verkuyten, 2003). Thus, the main dimensions of differentiation between Turkey and Europe are differences with respect to the EU criteria concerning economy and human rights and cultural/ religious differences reflected by the history of conflict. Furthermore, over time, Turkey lost and Europe has gained economic power.

Presently, Turkey and Greece have a conflict of interest over Cyprus, and Turkey is the only predominantly Muslim country seeking entry into the EU, and the only one whose membership was not accepted for over 50 years. In view of the history of conflict and religious differences, Turkey and Europe may be viewed as outgroups vis-à-vis each other. Although religion is an important dimension of differentiation between Turkey and Europe, the EU is referring to economic and human rights criteria as reasons for stalling/rejecting Turkey's application. These reasons are consistent with the immoral and low class image of the Turk depicted in European media (Aydin, 2003). In other words, Turkey as a low status group is trying to join a superordinate group which questions her qualifications for group membership. From that stance, the present study is an investigation of reactions of low status group members to obstruction of group social mobility.

\section{SOCIAL IDENTITIES, VALUES AND INTERGROUP RESPONSES WITHIN HISTORICAL CONTEXT}

The Self-Categorization version of Social Identity Theory views social identities as context-dependent and changeable (Oakes, Haslam, \& Turner, 1994). However, work with real life groups provides evidence for the presence of rather stable social identities based on historical divisions and/or positions within the social structure (Freeman, 2001). Furthermore, research demonstrates that ethnic-political identities are related to past intergroup relations, to different constructions of history, and to reactions to current intergroup issues (Doosje \& Branscombe, 2003; Hilton, Erb, Dermot, \& Molian, 1996; Liu, Wilson, McClure, \& Higgins, 1999). 
Recent research and theorizing implies that values may provide important links among historical context, social identities, and responses to intergroup situations. Nationalistic and authoritarian values were associated with discrimination against outgroups (Mummendey, Klink, \& Brown, 2001). A distinction between patriotism and nationalism was made (Duckitt \& Mphuthing, 1998). It was proposed that nationalism involves positive feelings towards one's nation but it is similar to authoritarianism and ethnocentrism in that it involves outgroup derogation. Patriotism, on the other hand, was defined as feelings of attachment to one's country independent of derogation of the outgroup.

Hitlin (2003) argues that values constitute the core of personal identity and lead to a feeling of transsituational stability of self. According to Hitlin, values lead to construction and/or adoption of social identities through enactment of value-consistent behaviours. Research has shown that the relations between values and identities (or ideologies) may differ depending on historical context. For example, different associations between values and ideology were demonstrated for eastern and western European countries (Kemmelmeier et al., 2003). Furthermore, values and identities were shown to reveal different patterns of associations for Blacks and Afrikaans in South Africa and for samples from USA and Indonesia (Haven, Stones, Sibayi, \& Le Roux, 2000; Jetten, Postmes, \& Mcauliffe, 2002).

\section{HISTORICAL ORIGINS OF POSSIBLE SOCIO-POLITICAL IDENTITIES IN CURRENT TURKEY}

Ottoman identity based on religion was rejected after the Republic, and a secular, western, progressive, peace loving, and humanitarian Turkish identity was constructed (Kuran-Burçoğlu, 2003). This identity was closely related to westernization attempts initiated in the 19th century (Kongar, 1998). However, it is argued that this new identity had an authoritarian element because it was dictated by elites (Kadığlu, 1997; Kasaba, 1999; Keyder, 1999). The new Republican identity also led to assimilationist policies toward Muslim minorities and tended to equate Turkish citizenship with Turkish ethnic origin. Presently, social democratic sectors endorse the Republican tradition, emphasizing humanistic and patriotic aspects and downplaying ethnic overtones. This identity may be called 'Kemalist' after the ideology of the founder of the Republic.

More nationalist ideologies emerged during the WWII. They found some support among university youth in the late sixties and were adopted by a very small minority until the seventies (Kongar, 1998). However, a political party with a fairly strong ethnicist stand was established after the 1970s and became the second party in the 1999 elections.

Westernization efforts during the 19th century led to reactions from religious-conservative sectors (Bora, 1997). Protests against the secular republican identity were suppressed after the republic (Kongar, 1998). Political parties exploited religion after the 1950s. Islamic orders revived after the 1960s and Islam gained strength in urban centres during the late 1980s (B. Akşit, paper presented at the conference on 'Dynamic of States and Societies in the Middle East', Cairo, 1989; Toprak, 1988). A post modern 'Moslem and modern' identity, which accepts western technology but does not embrace humanistic values, emerged in the 1990s as a result of top-down application of modernity and incompatibility between Islamic values and values related to equality and civil liberties (Keyder, 1999).

A brief review of historical developments in Turkey points to three different socio-political identities in Turkey. One identity appears to be a nationalistic one based on Turkish ethnicity. It is associated with the nationalist party and with ethnocentric values. This identity may be associated with distinctiveness seeking from the outgroup 'Europe,' perception of intergroup conflict, and outgroup derogation. A second identity seems to be based on religion and is likely to be associated with 
antisecularism. This identity should also be associated with the history of Ottoman-European conflict and with seeing Europe as a hostile outgroup which is different with respect to culture and religion. A third, the 'Kemalist,' identity is expected to be associated with patriotism and secularism and with positive views of the west. However, based on historical developments, this identity may also include ethnic overtones. Due to a rise in individualism (Esmer, 1999) and increased exposure to westernization and globalization, a 'western' or 'citizen of the world' fourth identity is also possible among urbanized youth from educated families.

A glance at historical developments indicates that authoritarianism, patriotism, religion, and secularism are associated with various socio-political identities in Turkey. Authoritarian-ethnocentric values are associated with educational and urban-rural criteria (Kağıtçıbaş1, 1973). Historical developments indicate that the nationalist identity should be associated with nationalism/ authoritarianism, distinctiveness seeking, and outgroup derogation. The religious identity may also involve authoritarian overtones, distinctiveness seeking, and outgroup derogation; however, the basis of this identity is expected to be religious and not ethnic. Consistent with Kemal Atatürk's dictum 'Turk, be proud, be confident, work,' the Kemalist identity should be associated with patriotism. The western identity should be secular and associated with acceptance of European superiority.

\section{CHARACTERISTICS OF THE INTERGROUP SITUATION}

Research on groups of unequal status revealed that low status group membership implies low value and low group level esteem (Weber, Mummendey, \& Waldzus, 2002). Low status groups often acknowledge superiority of the high status groups on status defining criteria, e.g. economic conditions in the case of European countries, but often claim superiority on alternate (often moral) criteria (Ellemers \& van Rijswicjk, 1997; Poppe \& Linssen, 1999; Schmit \& Maes, 2002; Vadinu \& Cerchioni, 2001). High status groups are generally more prototypic of the superordinate group, and low prototypicality of low status groups constitutes justification for their low status and inferior reward allocations (Wenzel, 2001).

Members of low status groups may endorse system justification beliefs, legitimize status differences, accept their low status, and may attempt social mobility (Pinel, 1999; Postmes, Branscombe, Spears, \& Young, 1999; Ruggiero \& Taylor, 1997). On the other hand; they may reject system justification beliefs, blame the system, demand retribution, and seek social change (Taylor \& McKirnan, 1984). Research and theory indicates that permeability and legitimacy of group boundaries, intra versus intergroup social comparison, attributions, and identification with subgroup determine low status group member's reactions to denial of entry into high status groups (Ellemers, Baretto, \& Spears, 1999; Tajfel, 1981; Mummendey, Kessler, Klink, Mielke, \& Wenzel, 1999; Taylor \& McKirnan, 1984). A minimal degree of permeability, perception of self as being close to the criteria of entry, system justification beliefs, seemingly acceptable reasons for exclusion, and blame attributions to in-group are associated with attempts at individual social mobility rather than group oriented attempts at social change (Hine \& Montiel, 1999; Kappen \& Branscombe, 2001; Sidanius \& Pratto, 1999; Wright, Taylor, \& Moghaddam, 1990).

The EU is a high status superordinate group into which Turkey is seeking acceptance. In trying to join the EU, Turkey behaves like a low status group accepting the legitimacy of its low status and attempting social mobility. The boundaries of the superordinate group, the EU, seem to be fairly but not completely impermeable. Research has shown that even a very low probability of acceptance into the high status group and the flimsiest explanation for rejection are sufficient for legitimization of exclusion and continuation of attempts at social mobility (Kappen \& Branscombe, 2001; Wright et al., 
1990). Thus, Turkey may continue her attempts at social mobility. However, after admission of Eastern European countries, doubts concerning the importance of historical and religious differences rather than economic and human rights criteria for rejection of Turkey's application have been raised in the Turkish media. In other words, doubts concerning permeability of the EU boundaries and discrimination based on religious and historical grounds were engendered.

Social Identity Theory would argue that acknowledgement of Turkey's low status (low prototypicality) in relation to the valued superordinate category would be associated with positive evaluation of the EU and with justification of the rejection, whereas viewing Turkey and Europe as opposing groups would lead to positive distinctiveness seeking and to negative reactions to the decision.

\section{OVERVIEW OF RESEARCH AND PREDICTIONS}

In the present study, university students were asked to indicate their degree of identification with various socio-political identities in the current Turkish scene, endorsement of a number of statements about the EU and the Copenhagen decision. Measures related to patriotism, ethnocentricism, authoritarianism, and religious values and indicators of parental education and rural-urban origin were also included in the study. Several predictions are proposed:

1. Both positive and negative constructions of the EU were expected. Positive constructions were expected to involve acceptance of the EU's superiority. Negative constructions were expected to emphasize historical and religious differences and past conflict.

2. Reactions to the decision could be either negative, citing pre-existing conflict and differences, or positive, citing justifications in terms of Turkey's inferior status.

3. (a) Positive constructions of the EU and justification of the Copenhagen decision and (b) negative constructions of EU and negative evaluation of the Copenhagen as a discriminatory act were expected to be related.

4. Three major social identities were expected: Nationalist, religious, and Kemalist. A fourth (western) identity was also possible.

5. (a) The Nationalistic identity was expected to be associated with ethnocentrism and authoritarianism, (b) the religious identity was expected to be associated with antisecularism, (c) the Kemalist identity was expected to be associated with patriotism and secularism, (d) and the western identity was expected to be related to secularism.

6. Nationalistic and religious identities should be related to constructions of the EU as a distinct and hostile outgroup. Therefore these identities should be associated with negative constructions of Europe.

\section{METHOD}

\section{Participants}

The sample consisted of 400 students (215 females and 154 males) from various faculties, departments and all years at five different universities: The universities were located in the three largest cities in Turkey: Istanbul, Ankara and Izmir. The mean age of participants was 19,86 years $(S D=1,36$, range 17-30). The sample showed variation with respect to urban-rural origin and parental education. 


\section{Questionnaires}

The first part of the questionnaire included questions about background information such as school, department, class, age, gender, and birthplace, place of residence, and parental education $(1=$ no education, $7=$ post graduate work $)$ and place of birth $(1=$ village, $5=$ metropolitan city $)$. The next section required the participants to indicate their degree of endorsement of 11 social identities in the form of 'I see myself as ...' on a 7-point scale ( $1=$ strongly agree, $4=$ neither agree nor disagree, $7=$ strongly disagree). The identities were citizen of the Turkish Republic, Muslim, world citizen, European/Westerner, conservative, nationalist, Kemalist, Turk, leftist, conservative-democrat, and liberal. Three items inquiring about the importance of political views for life (e.g. 'My political idea affects my life very much' ; $1=$ strongly agree, $7=$ strongly disagree) were also included.

The next section inquired about the degree of agreement with a number of statements about the EU. These statements were based on content analysis of newspapers representing various socio-political ideologies. ${ }^{1}$ The next section was about evaluations of the Copenhagen decision. Participants evaluated the decision by agreement with three statements. Participants also indicated agreement with several possible causes for the decision. Possible causes were economic and human rights conditions of Turkey, conflict about Cyprus, and European fear of unqualified manpower from Turkey, and religious differences. ${ }^{1}$ A section measuring personal subjective utility of entrance to the EU followed. In this section, participants were first asked to rate the importance of a number of outcomes for themselves and, next, to indicate whether entrance to the EU would increase or decrease the probability of attaining these outcomes. This section was not included in the analyses.

The next section included Authoritarianism, Patriotism, and Ethnocentrism scales adapted from Kağıtçıbaşı (1973). Kağıtçıbaşı's scales were updated with reference to the current social context. Items related to religious views were created in order to tap values associated with religious convictions. These items included views related to beliefs in the necessity of religious beliefs for a moral life and beliefs in the necessity of application of religious rules in governmental areas such as education and justice (antisecularism). ${ }^{1}$

\section{Procedure}

Questionnaires were either distributed during class hours to groups of students by instructors or students who responded to billboard advertisements participated in the research for course credit. Completion of questionnaires took about $30 \mathrm{~min}$. Students in two universities received course credit for their participation.

\section{RESULTS}

\section{Factor Analyses and Scale Construction}

\section{Constructions of the EU}

Preliminary analyses on items related to construction of the EU revealed that $20 \%$ of participants rated the 'I neither agree nor disagree' alternative for a number of statements. (A factor analysis with

\footnotetext{
${ }^{1}$ The items about the EU, evaluation of the Copenhagen decision, and religious views and factor loadings of items included in the factor analysis of items about EU may be obtained from the first author.
} 
varimax rotation revealed a ten factor solution where 18 items with unrelated meanings loaded on the first factor.) These statements were not included in further analyses because it appeared that they did not have much meaning for a sizable minority of our participants. Many items referring to positive aspects of the EU with respect to human rights criteria were among those that were excluded. The finding that most participants did not voice an opinion with respect to these aspects of the EU may mean that these issues were secondary at the time the research was conducted.

A varimax rotated factor analysis performed on the remaining 20 items resulted in five factors explaining $55 \%$ of the total variance. Examination of factor loadings and the scree plot led to the decision to adopt a three-factor solution. (Items loading above 0.33 were included under each factor. In the case of cross loadings, items were included under the factor on which they had the highest loading.) The first factor included items stressing religious difference and historical conflicts with Europe and was named Europe as Different. It explained $17 \%$ of the total variance and had an eigenvalue of 3.39. The second factor included items referring to European imperialism, exploitation, and discrimination, implying questioning of system justification beliefs based on economic and human rights criteria. It was labelled Impermeable Boundaries, explained 13\% of the variance, and had an eigenvalue of 2.55. The third factor included items citing positive aspects of the EU as well as differences between Turkey and Europe. This factor explained $11 \%$ of variance, had an eigenvalue of 2.11 and was labelled Dissimilar but Advantageous. Thus, consistent with prediction 1, both positive and negative views about the EU were evidenced. Three scales were constructed based on the three factors by averaging over all items characterizing each factor.

\section{Reactions to the Copenhagen Decision}

The first three items measuring evaluation of the decision were used as a scale named Evaluation. A factor analysis with varimax rotation conducted on the remaining eight items resulted in two factors explaining $43 \%$ of the total variance. The two factors of this solution were named 'Different-Conflict' and 'Justification.' The Different-Conflict factor included items citing religious differences and conflict of interest. This factor explained $24 \%$ of the total variance and had an eigenvalue of 1.97 . The second factor included items referring to economic conditions, unqualified Turkish workers, and human rights issues. It explained 19\% of total the variance, and had an eigenvalue of 1.55. Thus, consistent with prediction 2, one factor reflected system justification and the other reflected perception of discrimination by the outgroup. Two scales were constructed based on the two factors by averaging over all items characterizing each factor. ${ }^{1}$

\section{Values Related to Religion}

A factor analysis with varimax rotation was performed on items related to religion. Three factors emerged explaining $58 \%$ of the total variance. The first factor explained $26 \%$ of variance and had an eigenvalue of 2.81. It was named Religious Authoritarianism because it was composed of items rejecting and devaluing people who do not believe in religion. The second factor explained $21 \%$ of the variance, had an eigenvalue of 2.32 and was named Antisecularism because it included items opposing secularism. Two items loaded on the third factor which explained $11 \%$ of the variance and had an eigenvalue of 1.18. Items included in this factor, 'My religious belief does not restrict my freedom' (0.80) and 'Religiosity is a kind of opium that numbs people' (0.67), did not constitute a coherent whole. Two scales based on the first two factors were formed. The first factor appeared to be a religious

\footnotetext{
${ }^{1}$ See page 6.
} 
Table 1. Factor loadings of second order factor analyses, scale reliabilities and descriptive statistics

\begin{tabular}{lcrrrrr}
\hline & $\begin{array}{c}\text { Authoritarian } \\
\text { N-I }\end{array}$ & $\begin{array}{c}\text { Negative } \\
\text { views }\end{array}$ & $\begin{array}{c}\text { Kemalist- } \\
\text { Western }\end{array}$ & $\begin{array}{r}\text { Justify- } \\
\text { accept }\end{array}$ & $\begin{array}{c}M(S D) \\
\text { (range } 1-7)\end{array}$ & $\alpha$ \\
\hline Nationalistic-Islam identity & $\mathbf{0 . 8 0 0 *}$ & 0.160 & -0.261 & -0.047 & $4.13(1.64)$ & 0.73 \\
Antisecularism & $\mathbf{0 . 7 1 6}$ & 0.131 & 0.047 & 0.131 & $3.45(1.09)$ & 0.80 \\
Ethnocentricism & $\mathbf{0 . 6 5 1}$ & 0.362 & 0.003 & -0.315 & $3.17(0.78)$ & 0.72 \\
Religious authoritarianism & $\mathbf{0 . 5 4 0}$ & -0.124 & 0.021 & -0.033 & $2.33(3.25)$ & 0.77 \\
Authoritarianism & $\mathbf{0 . 4 5 6}$ & 0.226 & 0.142 & -0.315 & $3.22(0.71)$ & 0.63 \\
Different-Conflict & 0.089 & $\mathbf{0 . 7 4 4}$ & 0.069 & 0.163 & $4.45(1.33)$ & 0.55 \\
Impermeable boundaries & 0.049 & $\mathbf{0 . 6 9 7}$ & 0.135 & -0.380 & $4.72(1.19)$ & 0.71 \\
Evaluation (1= +, 7 - ) & 0.089 & $\mathbf{0 . 6 8 9}$ & 0.155 & -0.062 & $5.07(1.53)$ & 0.82 \\
Europe as different & 0.463 & $\mathbf{0 . 5 6 8}$ & 0.231 & -0.272 & $2.78(1.17)$ & 0.76 \\
Kemalist identity & 0.098 & -0.081 & $-\mathbf{0 . 8 3 9}$ & -0.253 & $5.74(1.63)$ & 0.77 \\
Western identity & -0.142 & -0.282 & $-\mathbf{0 . 5 7 8}$ & -0.056 & $4.66(1.80)$ & - \\
Patriotism & 0.495 & 0.183 & $-\mathbf{0 . 5 1 9}$ & 0.071 & $4.90(0.96)$ & 0.80 \\
Justification & -0.175 & 0.172 & -0.030 & $\mathbf{0 . 6 6 5}$ & $40.89(1.25)$ & 0.51 \\
Dissimilar but advantageous & 0.121 & -0.161 & 0.244 & $\mathbf{0 . 6 5 0}$ & $5.27(2.36)$ & 0.78 \\
\hline
\end{tabular}

* Measures loading on each dimension are in bold.

version of authoritarianism and factor two reflected Antisecularism, an important ideological issue of Turkey's past. Scale reliabilities were computed for all scales. Missing data were handled by substituting each participant's own scale mean for his/her missing item. Means, SDs and reliabilities of the scales are presented in the last columns of Table 1 .

\section{Social Identities}

Preliminary analyses on 11 social identity items showed that $30 \%$ of participants selected the 'neither acceptable nor unacceptable' alternative for two social identities: conservatist-democrat and liberal. These items were excluded from further analyses because it appeared that they did not have much meaning for our participants. A varimax factor analysis was performed on the remaining nine items and the resulting three factors explained $65 \%$ of variance. Nationalist $(0.71)$, Islam $(0.78)$, and conservative (0.80) identities loaded on the first factor which was named Nationalist-Islam (N-I), had an eigenvalue of 2.08 , and explained $26 \%$ of variance. Kemalist (0.85), Turk (0.71), and citizen of the Turkish Republic (0.74) loaded above on the second factor labelled Kemalist. This factor explained $23 \%$ of variance and had an eigenvalue of 1.82. The third factor included European/Western (0.70) and world citizen (0.80) identities, explained $17 \%$ of variance and had an eigenvalue of 1.32 . It was labelled Western-World. The item 'leftist' loaded positively on the second factor $(0.50)$ and negatively on the first $(-0.44)$ and third $(-0.34)$ factors. European/Western had a 0.35 loading on the second factor but it was included in the third factor because of its higher loading. Thus the results of the factor analysis on social identities revealed that the nationalist and religious identities merged and did not constitute separate identities as expected on the basis of historical developments. The Kemalist identity was distinguished from the Nationalist-Religious identity and the Western/European and citizen of the world identities merged. In short, prediction 4 was partially supported. Three scales were formed based on the results of the factor analysis. Leftist was not included in any of the scales because it had cross loadings on all three factors. The reliability of Western-World identity was unsatisfactory, therefore the single item European/Western was used in further analyses.

An ANOVA where endorsement levels of identities served as the within subjects variable and School and Gender served as between subjects variables revealed a significant effect due to type of 
identity endorsed, $F(2,386)=144.79, p<0.001, \eta^{2}=0.43 .^{2}$ All three identities differed from each other in terms of degree of endorsement, the Kemalist identity received the highest level of endorsement followed by Western and N-I (Table 1). Furthermore, when the participants were classified with respect to preference for one identity over the other two, 50\% preferred the Kemalist, 16.8 preferred the Western and $10.8 \%$ preferred the N-I identity. In addition, $12.8 \%$ indicated equal preference for Western and Turkish identities and 6.3\% indicated equal preference for Kemalist and NI identities. Less than $1 \%$ indicated equal preference for Western and N-I identities. Thus Kemalist identity appeared to be the modal one, overlapping with both of the other two identities. In addition, an index of urbanization based on $z$-scores of parental education and rural-urban place of birth $(\alpha=0.73)$ correlated positively with Western and negatively with N-I identities $(r=0.235$ and $r=-0.357$, $p s<0.01)$. The correlation was not significant for Kemalist identity $(r=0.040)$.

\section{Second Order Factor Analysis}

A varimax factor analysis conducted on the 14 scales revealed six factors explaining $71 \%$ of the variation. A four-factor solution explaining 54\% of the variation was adopted because one factor was characterized by a single scale and five scales had loadings above 0.33 on more than one factor on the six-factor solution. As may be seen in the first four columns of Table 1, Authoritarianism, Ethnocentrism, Religious Authoritarianism, Antisecularism scales and the N-I identity characterized the first factor which explained 19\% of the variance. Patriotism and Europe as Different scales also had loadings above 0.33 (explaining 10\% of variance) on this factor. This factor was labelled Authoritarian-Nationalist. It combined a social identity distinct from Europe with values implying hostility toward outgroups and antisecularism. The composition of this factor was consistent with the first part of prediction 5(a) concerning nationalist identity and its associated values.

Negative constructions of Europe (Impermeable Boundaries and Europe as Different scales) and negative reactions to the Copenhagen decision (Evaluation and Different-Conflict scales) loaded on the second factor which explained $16 \%$ of the variance and had an eigenvalue of 2.25 . This factor was labelled Negative Views, indicated that negative constructions of Europe and reactions to the decision were interconnected, and was consistent with prediction 3(b).

Kemalist and Western identities and Patriotism loaded on the third factor labelled KemalistWestern. This factor had an eigenvalue of 1.56 and explained $11 \%$ of the variance. The associations between Patriotism and Kemalism and between Kemalist and Western identities were consistent with prediction 5(b) and with the Western stance of Kemalist ideology. However, inconsistent with predictions 5(b) and 5(c), the results of the factor analysis revealed no associations between secularist beliefs and either of the Kemalist or Western identities.

The fourth factor included acceptance of European superiority (Dissimilar but Advantageous scale) and accepting Turkey's inferior status as justification for exclusion from the EU (Justification scale). Viewing the EU as having impermeable boundaries also had a loading above 0.33 on this factor. This factor had an eigenvalue of 1.41 , explained $10 \%$ of the variance and was labelled Justify-Accept. The finding that positive views of Europe and justifications of the Copenhagen decision loaded the same factor was consistent with prediction 4 .

\footnotetext{
${ }^{2}$ Analyses using School and Gender as independent variables were conducted and revealed that gender effects were nonsignificant. Significant school effects were found but they are not included in this report in view of the fact that they would be meaningless outside of Turkey.
} 


\section{Association Between Identities, Values and Views of Europe}

Prediction 6 stated that Nationalist and religious identities should be related to negative constructions of the EU. This prediction was tested by SEM where the latent variable Authoritarian-Nationalism was defined as the cause of both Positive and Negative Views toward the EU and the Copenhagen decision. Indicators of Authoritarian-Nationalism were Authoritarianism, Ethnocentrism, Religious Authoritarianism, Antisecularism scales and the N-I identity, indicators of Positive Views were Justification and Different but Advantageous, and indicators of Negative Views were on Europe as Different, Impermeable Boundaries, Difference and Conflict, and Evaluation scales. Although not part of the prediction, measures included in the index of urbanization comprised $z$-score transformations of parental education and rural-urban origin were included as predictors of the Authoritarian-Nationalist composite.

The fit of the model was not good. ${ }^{3}$ Modification indices suggested adding error covariances between Evaluation and Europe as different and Impermeable Boundaries and between mother's and father's education and rural-urban origin. These modifications were employed because they were consistent with the theoretical assumptions of the study. The revised model revealed improved fit. The $\chi^{2}(83, N=375)=183.019$ was still significant but reduced, with $\chi^{2} / \mathrm{df}$ ratio of $2.1, G F I=0.93$, $A G F I=0.91, P G F I=0.65, R M S E A=0.058,90$ per cent confidence interval for $R M S E A=0.047$; $0.069, p=0.10$ (Figure 1). Authoritarian-Nationalism explained $14 \%$ of the variation in positive and $48 \%$ of the variation for negative views of Europe. In addition, the urbanization index explained $27 \%$ of the variation in Authoritarian-Nationalism. Thus, prediction 6 received support.

An alternate model in which Authoritarian beliefs mediated between N-I identity and positive and negative views revealed poorer fit; $\chi^{2}(40, N=390)=172, G F I=0.92, A G F I=0.87, P G F I=0.56$, $R M S E A=0.095,90$ per cent confidence interval for $R M S E A=0.081 ; 0.11$. Another alternative model where values were excluded and Western and N-I identities were used as predictors of positive and negative views also revealed poorer fit than the first model; $\chi^{2}(16, N=390)=87.68, G F I=0.95$, $A G F I=0.89, P G F I=0.42, R M S E A=0.10,90$ per cent confidence interval for $R M S E A=0.082 ; 0.13$. This model also explained lower percentages of the variation for both positive (5) and negative (29) views than the first model. Thus, although the three models did not include the same variables and therefore were not strictly comparable, the first model appeared to be the best one both in terms of fit indices and amount of variation explained for positive and negative reactions.

\section{DISCUSSION}

The present study indicated the existence of three social identities among Turkish university youth. These were N-I, Kemalist, and Western-World identities. These three identities reflected the hybrid nature of the Turkish social scene where relics of the Ottoman Empire coexist with attempts at modernization and with exposure to globalization. The Kemalist identity received the highest level of endorsement followed by Western and N-I identities. Furthermore, it seemed to be the modal identity for the present sample and, judging from percentages indicating equal preference for more than one identity, it seemed to have some common ground with the other two identities. The finding that index of urbanization correlated positively with Western and negatively with $\mathrm{N}-\mathrm{I}$ identities implies that endorsement of the N-I identity may weaken and support for Western identity may increase with increasing urbanization. The finding that adherence to Kemalist identity is not related to urbanization implies that its popularity may be relatively stable in the future.

$\left.{ }^{3} \chi^{2}(87, N=375)=443.335\right) p<0.001, G F I=0.87, A G F I=0.82, P G F I=0.63, R M S E A=0.10,90$ per cent confidence interval for RMSEA $=0.09 ; 0.11$. 


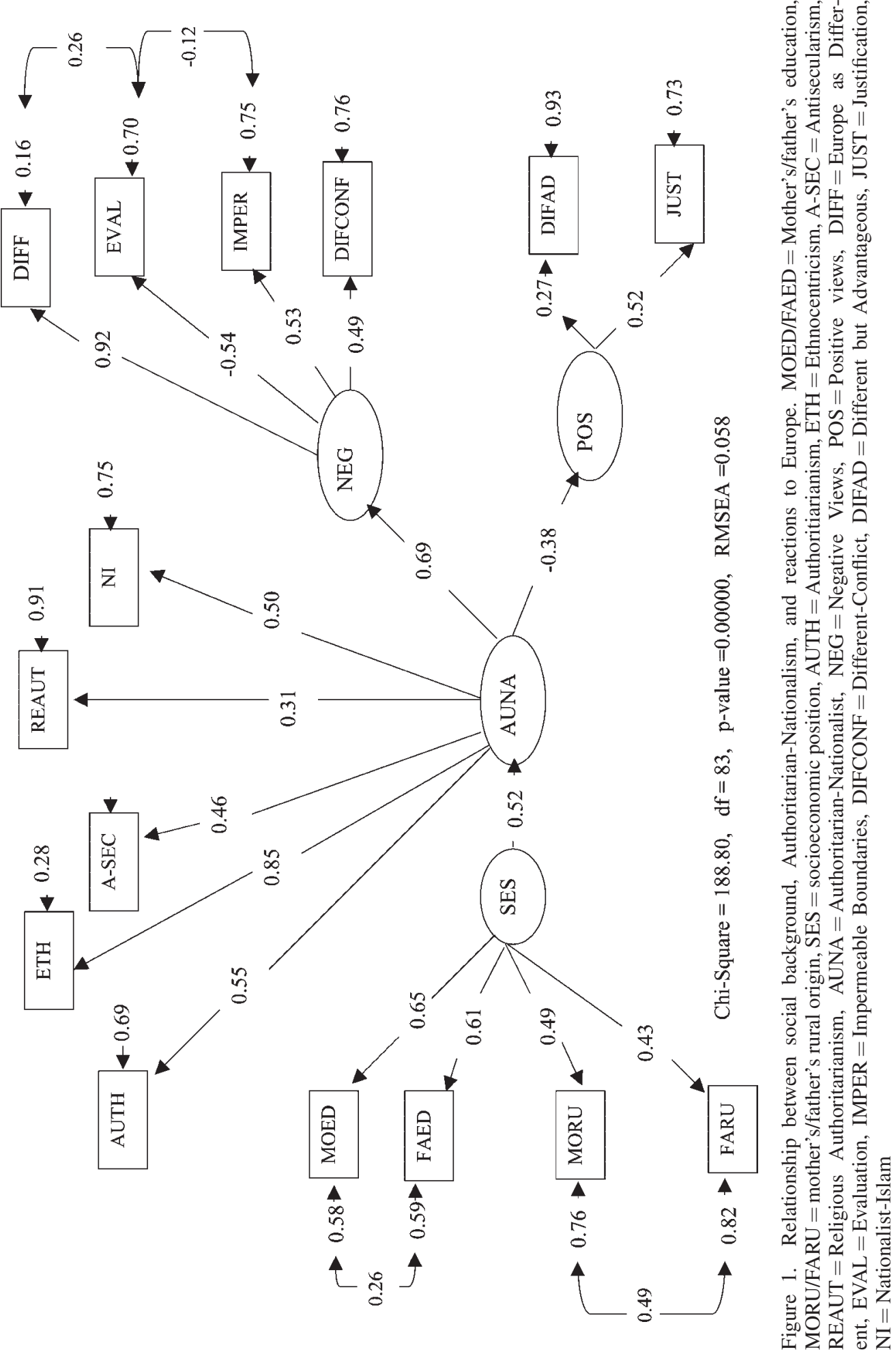


Nationalist and Religious identities were expected to constitute different identities, but they merged. This can be explained by the rising Islamic identity, emergence of religious branches of the Nationalist Movement Party (MHP) and the nationalist branches of religious parties during the last years, and with instability of political alliances in Turkey. The merger is also consistent with equating Turk with Islam and vice versa in the Turkish scene as well as abroad (Kongar, 1998).

Views of Europe and reactions to the Copenhagen decision were related and constituted two factors representing positive and negative views. The relationship between acknowledgement of European superiority and justification of the decision parallels the results of Hine and Montiel's (1999) investigation concerning explanations for poverty in developing countries. They found that Filipinos blamed corruption of the third world governments rather than exploitation by superpowers. The grouping of constructions of Europe as a discriminating outgroup and attributing the decision to conflict of interests also constituted a consistent package.

Overall, the constructions of the EU and reactionsto the Copenhagen decision were neutral, $M=-0.04(S D=0.97)$ and $M=0.07$ and $S D=0.84$ for negative and positive view factors (where $0=$ neither agree nor disagree). In the face of the controversial nature of the issue, this neutrality may be surprising. One explanation of this neutrality may be ambivalence resulting from past conflicts and differences together with acknowledgement of advantages of the EU and inferiority of Turkey vis-àvis the EU standards (i.e. low prototypicality with respect to superordinate category. Thus, Turkish students' reactions to the EU are similar to those of low status group members who wish social mobility but face boundaries which are almost but not totally impermeable (Wright et al., 1990).

The results of the second order factor analysis also revealed that values and identities were related. This was especially the case for the N-I identity, the identity representing the opposite pole from Christian Europe. This identity was grouped with ethnocentric, authoritarian, and antisecular values, i.e. values related to rejection of outgroups (Mummendey et al., 2001).

The results of the second order factor analysis revealed that Kemalist and Western identities were related and distinct from the N-I identity. Furthermore, both identities revealed positive relationships with patriotism. Thus, consistent with predictions, Kemalists were patriotic. However, the finding that patriotism had a positive loading on the factor including N-I and authoritarian values is against the distinction made between nationalism and patriotism (Mummendey et al., 2001). One explanation for this finding may be the argument that within the Turkish context, patriotism was introduced by the elites as part of a top-down process and consequently had authoritarian overtones (Kadıoğlu, 1997; Kasaba, 1999; Keyder, 1999). Furthermore, it is possible that relationships between different values may depend on the historical contexts of the social groups and/or countries in question (Haven et al., 2000; Kemmelmeier et al., 2003). Within the Turkish historical context, patriotism is associated with the war of independence against European powers.

$\mathrm{N}-\mathrm{I}$ identity and values related to rejection of outgroups constituted a package and predicted both positive and negative views of Europe. The finding that The N-I identity and the related value package was better at predicting negative than positive reactions was consistent with research on the association between nationalism and outgroup rejection (Leyens et al., 2003; Mummendey et al., 2001). Furthermore, supporting the view that identities may have social-structural antecedents (Deaux \& Martin, 2003), the authoritarian-nationalistic package was related to a low level of urbanization. In other words, it was associated with low intragroup status within a low status group (low socioeconomic position within Turkey). Thus, this identity-value cluster might have been associated with the highest level of identity threat and feelings of powerlessness. There is evidence that low status members of groups express high levels of negativity toward outgroups. For example, peripheral group members were shown to express more negativity toward outgroups than central members (Noel, Wann, \& Branscombe, 1995). Furthermore, Evans (1993) showed that powerlessness led to authoritarianism and authoritarianism led to rejection of system justification beliefs by low socioeconomic 
position participants. Thus, it is possible that both values and identities may be related to intragroup status, i.e. social-structural position.

The model which considered authoritarian values and N-I identity as a package seemed to be better at predicting reactions to Europe than either the model excluding values or the model treating values as mediators between identities and views of Europe. This finding as well as the finding that values and identities did not constitute different factors in the secondary factor analysis may be construed as support for Hitlin's (2003) argument that values constitute the core of personal identity and mediate between personal and social identities. Altman and Taylor (1973) also argued that values were at the core of personality and influenced attitudes and behaviours.

The present study had some limitations. First, it was correlational rather than longitudinal. A second limitation of the study was that it did not include a measure of different components of identification such as self-categorization, group commitment, and group esteem (Ellemers, Kortekaas, \& Ouwerkerk, 1999). Neither were measures of emotional reactions nor measures related to infrahumanization of outgroups included (Leyens et al., 2003). It is possible that such reactions may mediate between identity-value clusters and reactions to outgroups. Furthermore, participants were not representative of Turkish university youth. Given the (unreported) differences between students from different universities it is highly possible that students of other state or private universities might differ in their constructions of the EU. However, since students at different universities are likely to differ with respect to indicators of urbanization and this measure emerged as a significant predictor of Authoritarian-Nationalist composite, the model may apply to students of other Turkish universities.

In conclusion, the present study showed that values are important aspects of social identities and contributed to research linking values and social identities (Hitlin, 2003). Furthermore, it revealed that association between values and social identities depends both on historical context and also on intragroup factors. Thus, it implied that different values may be associated with different identities and provided support for arguments linking the concept of social identity to relatively stable social structural factors. Last, the study attempted a social psychological analysis of one of the most controversial topics in Turkey's current agenda. The analysis was based on theory and concepts at various levels, such as individual values, social identities, historical context and reactions to the outgroup. The results of the study with respect to social identities and construction of Europe showed some similarities to work and arguments of scholars from disciplines other than social psychology. As such, in the spirit of Sherif (1966) and Tajfel (1981), the present investigation was one of few studies that integrated ideas from several disciplines toward analysis of a current issue.

\section{ACKNOWLEDGEMENT}

This research was supported by a BAP grant 2003-07-03-00-04 from METUand is based on the data collected toward the Master's thesis of the second author.

The authors would like to thank Ercan Alp, Bengü Ergüner for help with data collection, to Başak

Ok for editing, to Gürkan Tekman for comments on an earlier draft, and to Çiğgdem Kağıtçıbaşı for permission to use and adapt her scales.

\section{REFERENCES}

Altman, I., \& Taylor, F. A. (1973). Social penetration: The development of interpersonal relationships. New York: Holt, Rinehart \& Winston.

Copyright (C) 2004 John Wiley \& Sons, Ltd.

Eur. J. Soc. Psychol. 35, 107-121 (2005) 
Aydin, K. (2003). A popular representation of Turkey into the 21th century: From verbal to visual. In M. Soykut (Ed.), Historical image of the Turk in Europe: 15th century to the present: Political and civilisation aspects (pp. 309-324). Istanbul: Isis press.

Bora, T. (1997). Cumhuriyetin ilk döneminde milli kimlik (National identity during the first era of the Republic). In N. Bilgin (Ed.), Cumhuriyet, demokrasi ve kimlik (Republic, democracy and identity) (pp. 53-62). Istanbul: Bağlam Yayıncılik.

Deaux, K., \& Martin, D. (2003). Interpersonal networks and social categories: Specifying levels of context in identity processes. Social Psychology Quarterly, 66, 101-117.

Doosje, B., \& Branscombe, N. R. (2003). Attributions for the negative historical actions of a group. European Journal of Social Psychology, 33, 235-248.

Duckitt, J., \& Mphuthing, T. (1998). Group identification and intergroup attitudes: A longitudinal analysis in South Africa. Journal of Personality and Social Psychology, 74, 80-85.

Ellemers, N., Barretto, M., \& Spears, R. (1999). Commitment and strategic responses to social context. In N. Ellemers, R. Spears, \& B. Doosje (Eds.), Social identity: Context, commitment, content (pp. 127-146). Oxford: Blackwell.

Ellemers, N., Kortekaas, P., \& Ouwerkerk, J. W. (1999). Self-categorisation, commitment to the group and group self-esteem as related but distinct aspects of social identity. European Journal of Social Psychology, 29, 371389.

Ellemers, N., \& van Rijswicjk, W. (1997). Identity needs versus social opportunities: The use of group-level and individual-level identity management strategies. Social Psychology Quarterly, 60, 52-65.

Esmer, Y. (1999). Devrim, evrim, statüko: Türkiye'de sosyal siyasal ekonomik değerler (Revolution, evolution and status quo: Social, political and economic values in Turkey) TESEV Yayınları no 7: stanbul: Acar.

Evans, G. (1993). Class, powerlessness and political polarization. European Journal of Social Psychology, 23, 495-511.

Freeman, M. (2001). Linking self and social structure: A psychological perpective on social identity in Sri Lanka. Journal of Cross-Cultural Psychology, 32, 292-308.

Haven, P. C. L., Stones, C., Sibayi, L., \& Le Roux, A. (2000). Human values and social identities among samples of white and black South Africans. International Journal of Psychology, 33, 67-72.

Hilton, J. H., Erb, H., Dermot, M., \& Molian, D. J. (1996). Social representations of history and attitudes to European Unification in Britain, France and Germany. In C. M. Breakwell, \& E. Lyons (Eds.), Changing European identities: Social psychological analyses of social change (pp. 275-295). Oxford: BetterworthHeinemann.

Hine, D. W., \& Montiel, C. J. (1999). Poverty in developing nations: A cross-cultural attributional analysis. European Journal of Social Psychology, 29, 943-959.

Hitlin, S. (2003). Values as the core of personal identity: Drawing links between the two theories of self. Social Psychology Quarterly, 66, 118-137.

Jetten, J., Postmes, T., \& Mcauliffe, B. J. (2002). 'We're all individuals': Group norms of individualism and collectivism, levels of identification and identity threat. European Journal of Social Psychology, 32, 189-207.

Kadığlu, A. (1997). Cumhuriyetin kuruluş yıllarında Türk milliyetçiliğinin çelişkisi ve seçkinlerin tavrı (Contradictions of Turkish nationalism and attitudes of elites during the foundation years of the republic). In N. Bilgin (Ed.), Cumhuriyet, demokrasi ve kimlik (Republic, democracy and identity) (pp. 277-282). stanbul: Bağlam Yayıncılık.

Kağıtçıbaşı, Ç. (1973). Gençlerin tutumları: Kültürlerarası bir karşılaştırma. (Attitudes of youth: A crosscultural comparison). Ankara: Ortadoğu Teknik Üniversitesi.

Kappen, D. M., \& Branscombe, N. B. (2001). The effects of reasons given for ineligibility on perceived gender discrimination and feelings of injustice. British Journal of Social Psychology, 40, 295-313.

Kasaba, R. (1999). Eski ile yeni arasında Kemalizm ve modernizm (Kemalism and modernism between the old and the new). In S. Bozdoğan, \& R. Kasaba (Eds.), Türkiye'de modernleşme ve Ulusal kimlik (Modernization and national identity in Turkey) (pp. 12-28). stanbul: Numune Matbaacilik.

Kemmelmeier, M., Burnstein, E., Krumov, K., Genkova, P., Kanagawa, C., Hirshberg, M. S., Erb, H.-P., Wieczorkowska, G., \& Noels, K. A. (2003). Individualism, collectivism, and authoritarianism in seven socieities. Journal of Cross-Cultural Psychology, 34, 304-322.

Keyder, Ç. (1999). 1990'larda Türkiye'de Modernleşmenin Doğrultusu (Direction of modernization in Turkey in the 1990s). In S. Bozdoğan, \& R. Kasaba (Eds.), Türkiye'de modernleşme ve ulusal kimlik (Modernization and national identity in Turkey) (pp. 29-42). stanbul: Numune Matbaacilik.

Kongar, E. (1998). 21. Yüzyllda Türkiye: 2000'li yıllarda Türkiye'nin toplumsal yapısı (Social structure of Turkey in the 2000s). Istanbul: Remzi Kitabevi. 
Kuran-Burçoğlu, N. (2003). A glimpse at various stages of the evolution of the image of the 'Turk' in Europe 15th to 21 st centuries. In M. Soykut (Ed.), Historical image of the Turk in Europe: 15th century to the present: Political and civilisation Aspects (pp. 21-42). Istanbul: Isis Press.

Leyens, J.-P., Cortes, B., Demoulin, S., Dovidio, J. F., Fiske, S. T., Gaunt, R., Paladino, M.-P., Rodriguez-Perez, A., Rodriguez-Torres, R., \& Vaes, J. (2003). Emotional prejudice, essentialism, and nationalism. European Journal of Social Psychology, 33, 703-717.

Liu, J. H., Wilson, M. S., McClure, J., \& Higgins, T. R. (1999). Social identity and the perception of history: Cultural representations of Aotearoa/New Zealand. European Journal of Social Psychology, 29, 1021-1047.

Mummendey, A., Kessler, T., Klink, A., Mielke, R., \& Wenzel, M. (1999). Strategies to cope with negative identity: Predictions by social identity theory and relative deprivation theory. Journal of Personality and Social Psychology, 76, 229-245.

Mummendey, A., Klink, A., \& Brown, R. (2001). Nationalism and patriotism: National identification and outgroup rejection. British Journal of Social Psychology, 40, 159-172.

Noel, J. G., Wann, D. L., \& Branscombe, N. R. (1995). Peripheral ingroup membership status and public negativity toward outgroups. Journal of Personality and Social Psychology, 68, 127-137.

Oakes, P. J., Haslam, S. A., \& Turner, J. C. (1994). Stereotyping and social reality. Oxford: Blackwell.

Pinel, E. C. (1999). Stigma consciousness: The psychological legacy of social stereotypes. Journal of Personality and Social Psychology, 76, 114-128.

Poppe, E., \& Linssen, H. (1999). Ingroup favouritism and the reflection of realistic dimensions of difference between national states in Central and Eastern European nationality stereotypes. British Journal of Social Psychology, 38, 85-102.

Postmes, T., Branscombe, N. R., Spears, R., \& Young, H. (1999). Comparative processes in personal and group judgments: Resolving the discrepancy. Journal of Personality and Social Psychology, 76, 320-338.

Ruggiero, K. M., \& Taylor, D. M. (1997). Why minority members perceive or do not perceive the discrimination that confronts them: The role of self-esteem and perceived control. Journal of Personality and Social Psychology, 72, 373-389.

Schmit, M., \& Maes, J. (2002). Stereotypic ingroup bias as self-defence against relative deprivation: Evidence from a longitudinal study of the German Unification process. European Journal of Social Psychology, 32, 309326.

Sherif, M. (1966). Group conflict and co-operation. London: Routledge \& Kegan Paul.

Sidanius, J., \& Pratto, F. (1999). Social dominance: An intergroup theory of social hierarchy and oppression. Cambridge: Cambridge University Press.

Soykut, M. (2003). Image of the 'Turk' in Italy: A history of the 'other' in Early Modern Europe. Klaus Schwarz Verlang: Berlin. In M. Soykut (Ed.), Historical image of the Turk in Europe: 15th century to the present: Political and civilisational aspects (pp. 45-116). Istanbul: Isis Press.

Tajfel, H. (1981). Human groups and social categories: Studies in social psychology. Cambridge: Cambridge University Press.

Taylor, D. M., \& McKirnan, D. J. (1984). A five-stage model of intergroup relations. British Journal of Social Psychology, 23, 291-300.

Toprak, B. (1988). The State, Politics, and Religion in Turkey. In M. Heper, \& A. Evin (Eds.), State, democracy and the military: Turkey in the 1980's (pp. 119-136). Berlin: de Gruyter.

Vadinu, M. R., \& Cerchioni, M. (2001). Compensatory biases after ingroup threat: 'Yeah, but we have a good personality.' European Journal of Social Psychology, 31, 353-367.

Verkuyten, M. (2003). Discourses about ethnic group (de-)essentialism: Opressive and progressive aspects. British Journal of Social Psychology, 42, 371-391.

Weber, U., Mummendey, A., \& Waldzus, S. (2002). Perceived legitimacy of intragroup status differences: Its prediction by relative ingroup prototypicality. European Journal of Social Psychology, 32, 449-470.

Wenzel, M. (2001). A social categorization approach to distributive justice: Social identity as the link between relevance of inputs, and need for justice. British Journal of Social Psychology, 40, 315-335.

Wright, S. C., Taylor, D. M., \& Moghaddam, F. M. (1990). Responding to membership in a disadvantaged group: From acceptance to collective protest. Journal of Personality and Social Psychology, 58, 994-1003. 